Halaman 68-77

\title{
Pengaruh Penerapan PQ4R Terhadap Hasil Belajar Biologi Siswa Kelas X SMA Negeri 1 Mojolaban Tahun Pelajaran 2012/2013
}

\author{
The Influence of PQ4R Toward Biology Learning Achievement of X Degree Students \\ at SMA Negeri 1 Mojolaban in Academic Year 2012/2013 \\ Istiqomah Wahyu Pradana, Slamet Santosa, Marjono \\ Pendidikan Biologi FKIP Universitas Sebelas Maret \\ Jl. Ir. Sutami 36 A Surakarta \\ Email: wahyoeajeng@ rocketmail.com
}

Diterima 23 Juli 2013, disetujui 8 September 2013

\begin{abstract}
The aim of this research is to know the influence of PQ4R strategy toward biology learning achievement of X degree students at SMA Negeri 1 Mojolaban in 2012/ 2013 academic year. This research was quasi experiment research which used posttest only Nonequivalent control group design. This research applyed PQ4R strategy in experimental group and deduktif approach with discussion, classical course and questionanswer method in control group. Population's research is the entire class $\mathrm{X}$ at SMA Negeri 1 Mojolaban in academic year 2012/2013. Sampling techniques used cluster sampling. Cluster result has chosen X5 as experiment group and X7 as control group. Data was collected using multiple choice test, observation sheet, and document. The data were analyzed by t-test. This research concluded that application of PQ4R strategy has taken good effect toward student's achievement cognitive, psychomotor, and affective domain in learning biology of SMA Negeri 1 Mojolaban.
\end{abstract}

Key Words: PQ4R strategy, Biology Learning Achievement

\section{Pendahuluan}

Pendidikan yang mampu
mendukung pembangunan di masa
mendatang adalah pendidikan yang
mampu mengembangkan potensi peserta didik, sehingga mampu menghadapi dan mengatasi permasalahan yang dihadapinya. (Trianto, 2009). Pembela jaran Biologi merupakan bagian Ilmu $\begin{array}{ccc}\text { Pengetahuan } & \text { Alam (IPA) } & \text { yang } \\ \text { pengaruhnya } & \text { mencakup } & \text { ilmu } \\ \text { pengetahuan } & \text { dan teknologi. } & \text { Ilmu }\end{array}$ Pengetahuan Alam juga berperan penting dalam usaha membentuk manusia yang berkualitas. Pembelajaran biologi memerlukan strategi yang dapat melibatkan siswa seoptimal mungkin baik secara intelektual maupun emosional (Yusuf dan Natalina, 2005).

Tiemensma (2009) mengatakan bahwa membaca adalah komponen terpenting di abad 21 agar bisa bertahan di era globalisasi saat ini. Keberhasilan anak didik dalam mengikuti kegiatan belajar mengajar di sekolah ditentukan kemampuannya untuk memperoleh pengetahuan.

$$
\text { Sikap positif terhadap }
$$
pembelajaran biologi merupakan syarat keberhasilan peserta didik dalam belajar biologi dan meningkatnya minat peserta didik terhadap materi biologi. 
Penguasaan konsep dan prinsip biologi awalnya rendah disertai dengan sikap negatif terhadap pelajaran biologi, sulit diharapkan peserta didik akan berhasil dengan baik dalam pembelajaran biologi selanjutnya (Setiawan, 2008).

Proses pembelajaran berjalan secara optimal perlu adanya rencana pembuatan strategi pembelajaran. Strategi pembelajaran merupakan pola kegiatan pembelajaran berurutan yang diterapkan untuk mencapai suatu hasil belajar siswa (Trianto, 2009). Keberhasilan proses dan hasil pembelajaran di kelas dipengaruhi beberapa faktor antara lain adalah guru dan siswa. Penguasaan materi guru juga dituntut untuk menguasai strategi-strategi penyampaian materi, guru yang dapat menciptakan suasana kelas akan berpengaruh terhadap respon siswa dan menyebabkan siswa termotivasi aktif dalam belajar sehingga memungkinkan terjadi peningkatan hasil belajar (Yusuf dan Natalina, 2005). Hasil belajar merupakan kemampuan yang dimiliki siswa setelah mengalami proses belajar atau pembelajaran. Hasil belajar dalam pendidikan nasional menggunakan klasifikasi hasil belajar Bloom yang secara garis besar membaginya menjadi 3 ranah yaitu ranah afektif, ranah kognitif dan ranah psikomotorik (Sudjana, 2010).
Masalah dalam dunia pendidikan salah satunya adalah lemahnya proses pembelajaran di sekolah. Pembelajaran di sekolah masih banyak yang menggunakan cara konvensional dalam mengajar yang mengakibatkan siswa kurang didorong untuk mengembangkan kemampuan berpikir. Guru hanya mentransfer ilmu ke peserta didik tanpa memperhatikan kemampuan siswa yang berbeda-beda. Pembelajaran cenderung monoton dan membuat siswa bosan, sehingga menyebabkan siswa menjadi malas, kurang bersemangat dan cenderung pasif dalam kegiatan pembelajaran.

Permasalahan muncul karena kurangnya keaktifan dari siswa sendiri atau siswa jenuh dengan strategi yang dipakai oleh guru selama ini. Penggunaan model yang monoton dapat mempengaruhi keaktifan siswa untuk belajar Biologi. Guru harus dapat menerapkan berbagai model pembelajaran yang bervariasi, yang bisa mengubah cara belajar siswa dari pasif menjadi aktif sehingga akan membuat siswa tertarik dan paham dengan apa yang diajarkan oleh guru. Mengantisipasi masalah tersebut agar tidak berkelanjutan maka perlu diterapkan strategi pembelajaran yang tepat, sehingga dapat meningkatkan keaktifan siswa dalam pembelajaran Biologi. 
Salah satu cara untuk mengatasi masalah yang telah dikemukakan di atas yaitu dengan menerapkan strategi pembelajaran aktif. Menurut Zaini (2002), strategi pembelajaran aktif bertujuan untuk menumbuhkan jiwa kemandirian dan kreativitas dalam belajar sehingga siswa mampu membuat inovasi-inovasi.

Strategi pembelajaran aktif yang dapat digunakan salah satunya dengan menggunakan pembelajaran tipe $P Q 4 R$ (Preview, Question, Read, Reflect, Recite, Review). Strategi PQ4R digunakan untuk membantu siswa mengingat apa yang mereka baca. $\mathrm{P}$ singkatan dari preview (membaca selintas dengan cepat), $\mathrm{Q}$ adalah question (bertanya), dan $4 \mathrm{R}$ singkatan dari read (membaca), reflect (refleksi), recite (tanya jawab), dan review (pengulangan) (Trianto, 2009).

Strategi ini meningkatkan kinerja memori dalam memahami substansi teks yang dapat mendorong siswa mengolah materi secara lebih luas. $P Q 4 R$ merupakan salah satu bagian dari strategi elaborasi. Strategi ini digunakan untuk membantu siswa mengingat apa yang mereka baca, dan dapat membantu proses belajar mengajar di kelas yang dilaksanakan dengan kegiatan membaca buku. Kegiatan ini bertujuan untuk mempelajari materi mata pelajaran. Oleh karena itu keterampilan pokok pertama yang harus dikembangkan dan dikuasai para siswa adalah membaca buku pelajaran (Rachanah dkk, 2009). Membaca dapat dipandang sebagai sebagai proses interaktif antara bahasa dan pikiran. $P Q 4 R$ dapat membantu siswa dalam memahami materi pembelajaran, terutama terhadap materi yang sukar dan menolong siswa untuk berkonsentrasi lebih lama.

Teori yang mendasari strategi belajar $P Q 4 R$ menurut Trianto (2009) strategi belajar merujuk pada perilaku dan proses pikiran yang digunakan siswa akan mempengaruhi hal yang dipelajarinya termasuk ingatan dan proses metakognitif.

Penelitian ini bertujuan untuk mengetahui pengaruh strategi $P Q 4 R$ terhadap hasil belajar biologi siswa kelas $\mathrm{X}$ SMA Negeri 1 Mojolaban tahun pelajaran 2012/2013.

\section{Metode Penelitian}

Penelitian dilaksanakan di SMA Negeri 1 Mojolaban pada semester genap tahun pelajaran 2012/2013. Penelitian ini termasuk quasy eksperimental dengan pendekatan kuantitatif. Desain penelitian adalah Posttest Only Nonequivalent Control Group Design dengan menggunakan kelompok eksperimen (penerapan strategi $P Q 4 R$ ) dan kontrol 
(pembelajaran ekspositori dengan ceramah, tanya jawab, dan evaluasi).

Populasi dalam penelitian ini adalah seluruh siswa kelas X SMA Negeri 1 Mojolaban. Teknik pengambilan sampel dengan cluster sampling. Hasil pemilihan sampel menetapkan kelas X5 dengan siswa sejumlah 36 orang sebagai kelompok eksperimen menerapkan strategi $P Q 4 R$. Kelas X7 dengan siswa sebanyak 35 orang sebagai kelompok kontrol menerapkan pembelajaran ekspositori.

Variabel bebas berupa strategi $P Q 4 R$ dan variabel terikat adalah hasil belajar biologi siswa yang mencakup ranah kognitif, afektif, dan psikomotorik. Teknik pengumpulan data yang digunakan dalam penelitian ini adalah dokumentasi, tes dan observasi. Metode dokumentasi pada penelitian ini berupa dokumen hasil belajar yang diolah satu semester dengan nilai asli yang digunakan untuk mengetahui nilai kemampuan awal siswa berdasarkan nilai hasil belajar biologi. Metode tes digunakan untuk mengambil data hasil belajar ranah kognitif. Metode observasi dalam penelitian ini digunakan untuk mengukur hasil belajar ranah psikomotorik, ranah afektif dan keterlaksanaan rancangan pembelajaran.

Analisis data pada penelitian dengan menggunakan uji t. Sebelum dilakukan analisis data, maka dilakukan uji normalitas menggunakan uji Kolmogorov-Smirnov dan uji homogenitas dengan uji Levene's.

\section{Hasil dan Pembahasan}

Hasil analisis pengaruh penerapan strategi $P Q 4 R$ terhadap hasil belajar biologi siswa kelas X SMA Negeri 1 Mojolaban disajikan pada Tabel 1.

Tabel 1. Hasil Analisis Pengaruh Strategi $P Q 4 R$ terhadap Hasil Belajar Biologi.

\begin{tabular}{|c|c|c|c|c|c|}
\hline Ranah & $\mathrm{t}$ & $\mathrm{df}$ & Sig & $\begin{array}{l}\mathrm{t}_{(0.025,6} \\
2)\end{array}$ & $\begin{array}{l}\text { Keterang } \\
\text { an }\end{array}$ \\
\hline $\begin{array}{l}\text { Kogni } \\
\text {-tif }\end{array}$ & 7,220 & $\begin{array}{l}6 \\
9 \\
\end{array}$ & $\begin{array}{l}0,00 \\
0\end{array}$ & 1,994 & $\begin{array}{ll}\text { sig } & < \\
0,050 & \end{array}$ \\
\hline $\begin{array}{l}\text { Afekti } \\
\mathrm{f}\end{array}$ & $\begin{array}{l}16,53 \\
3\end{array}$ & $\begin{array}{l}6 \\
9 \\
\end{array}$ & $\begin{array}{l}0,00 \\
0\end{array}$ & 1,994 & $\begin{array}{ll}\text { sig } & < \\
0,050 & \end{array}$ \\
\hline $\begin{array}{l}\text { Psiko- } \\
\text { motori } \\
\mathrm{k}\end{array}$ & 3,017 & $\begin{array}{l}6 \\
9\end{array}$ & $\begin{array}{l}0,00 \\
4\end{array}$ & 1,994 & $\begin{array}{ll}\text { sig } & < \\
0,050\end{array}$ \\
\hline
\end{tabular}

Tabel 1 menunjukan bahwa sig. $<0,050$ pada semua ranah hasil belajar sehingga $\mathrm{H}_{0}$ ditolak pada semua ranah, hal ini berarti penerapan strategi $P Q 4 R$ berpengaruh nyata terhadap hasil belajar biologi pada ranah kognitif, afektif dan psikomotorik

Pengaruh tersebut bersifat positif. Pernyataan tersebut juga didukung secara deskriptif yaitu dari data nilai rata-rata hasil belajar ranah kognitif sebesar 88,240., ranah psikomotor sebesar 73,611., dan afektif sebesar 80,034., untuk siswa kelas eksperimen. Sedangkan untuk kelas kontrol memperoleh rata-rata hasil belajar ranah kognitif sebesar 79,714., psikomotor sebesar 57,857., dan afektif sebesar 64,702 . 
Hasil belajar biologi siswa di kelas eksperimen yang menggunakan $P Q 4 R$ dalam pembelajaran lebih tinggi dibandingkan dengan kelas kontrol yang menggunakan metode ceramah, tanya jawab, dan evaluasi. Hal ini disebabkan karena pembelajaran $P Q 4 R$ pada materi limbah dan daur ulangnya yang mencakup pengertian limbah, macammacam limbah, dampak limbah bagi lingkungan serta penanganan daur ulang limbah, memberi kesempatan yang luas kepada siswa untuk mengeksplorasi diri melalui kegiatan pembelajaran yang dilakukan.

$P Q 4 R$ membantu siswa untuk memfokuskan perhatian pada proses pembelajaran yang sedang berlangsung, karena di dalam pembelajaran $P Q 4 R$ ini terdapat tahapan-tahapan belajar yang memanfaatkan keterampilan siswa dalam memahami bacaan dan menelaah materi. Penelitian ini memang tidak menguji gaya belajar satu persatu, namun mengatur proses pembelajaran agar mampu mengakomodasi gaya belajar secara maksimal karena gaya belajar sangat berpengaruh terhadap hasil belajar (Tanta, 2010).

$P Q 4 R$ membantu siswa meningkatkan pemahaman siswa mengenai materi limbah yang sedang dipelajari sehingga hasil belajar siswa dapat meningkat (Puspito, 2012).
Pembelajaran $P Q 4 R$ menjadikan siswa lebih aktif dan tidak ada yang melakukan kegiatan lain selama proses pembelajaran, sedangkan siswa yang menerapkan metode ceramah dan tanya jawab cenderung pasif, mengantuk dan tidak fokus terhadap proses pembelajaran.

Langkah pertama dalam $P Q 4 R$ yaitu Preview yang berarti peserta didik menemukan ide-ide pokok dari materi limbah yang akan dipelajari dengan handout materi yang sudah diberikan. Siswa dapat menemukan sendiri poinpoin dari pengertian limbah, jenis-jenis limbah, dampak yang ditimbulkan limbah serta penanganan daur ulangnya. Suprijono (2009) menegaskan fokus dari preview adalah penemuan ide pokok dari materi sehingga siswa mempunyai gambaran mengenai hal yang akan dipelajarinya.

Langkah kedua dalam $P Q 4 R$ yaitu Questions atau bertanya yang mengarahkan siswa untuk merumuskan pertanyaan-pertanyaan dari yang sederhana menuju yang kompleks berdasarkan materi tentang limbah yang dipelajari. Tingkatan dan jumlah pertanyaan yang muncul dapat menjadi acuan untuk mengetahui latar belakang pengetahuan siswa dalam tahapan preview sebelumnya. Pada tahapan ini siswa akan membuat pertanyaan- 
pertanyaan yang berkaitan dengan pengertian limbah, jenis-jenis limbah, dampak yang ditimbulkan limbah, serta cara penanganan limbah dengan daur ulang. Syah (2005) menyatakan apabila materi yang sedang dipelajari siswa berisi hal-hal yang sebelumnya sudah diketahui, siswa hanya perlu membuat beberapa pertanyaan. Sebaliknya apabila latar belakang pengetahuan siswa tidak berhubungan dengan isi teks, maka siswa perlu menyusun pertanyaan banyak untuk dapat memahami materi.

Aktivitas pengajuan pertanyaan yang bermutu tinggi merupakan salah satu keterampilan yang harus ditekankan pada level pengembangan abstraksi dalam mengajarkan pemecahan masalah dan berpikir kritis (Jensen, 2011).

Langkah ketiga dalam $P Q 4 R$ adalah membaca (read) yang memfokuskan siswa untuk membaca materi dan menanggapi atau menjawab pertanyaan yang telah disusun sebelumnya. Syah (2005) menyatakan bahwa strategi $P Q 4 R$ pada hakikatnya merupakan penimbul pertanyaan dan tanya jawab yang mendorong siswa membaca materi untuk melakukan pengolahan materi secara mendalam dan luas. Pada tahapan ini siswa akan membaca materi limbah dari handout yang telah diberikan guru untuk mencari informasi dari daftar pertanyaan yang dibuat sebelumnya. Dari kegiatan ini siswa dapat menemukan pemahaman dengan mensinkronkan pertanyaan dan jawaban dari proses pemahaman membaca yang mendalam.

Joyce (2009) menegaskan bahwa pengajaran membaca, tujuan utamanya adalah meningkatkan kemampuan siswa dalam berpikir dan memahami bacaan yang pada akhirnya dapat meningkatkan efektivitas siswa

Langkah keempat dalam $P Q 4 R$ adalah tanggapan (reflect). Pada kegiatan pembelajaran ini siswa akan didorong untuk menggali pemahaman dari kegiatan langkah-langkah sebelumnya. Siswa pada tahap ini akan mempresentasikan hasil dari kegiatan diskusi pertanyaan dan jawaban-jawaban yang muncul dari kelompoknya. Kegiatan diskusi dilakukan pada pertemuan pertama dan kedua. Seluruh siswa dibagi menjadi enam kelompok dan tiap siswa diberi LKS yang berisi permasalahan dan pedoman pelaksanaan diskusi. Pada pertemuan pertama siswa harus berdiskusi untuk memecahkan permasalahan terkait pengertian limbah dan pengelompokan limbah. Diskusi pada pertemuan kedua digunakan untuk mendiskusikan mengenai dampak limbah bagi lingkungan dan cara penanganannya dengan cara daur ulang limbah. Kegiatan 
diskusi ini diakhiri dengan presentasi hasil diskusi.

Kegiatan diskusi dan presentasi mampu membuat siswa mendengarkan pendapat dari kelompok lain sehingga terjadi pertukaran pikiran antar siswa. Hal tersebuat membuat terjadinya interaksi yang baik antar siswa maupun interaksi siswa dengan guru serta mampu meningkatkan kemampuan berkomuni kasi. Siswandi (2006) menambahkan kemampuan berkomunikasi dapat meningkatkan kemampuan berpikir, bernalar, kemampuan memperluas wawasan, dan kemampuan untuk menanggapi persoalan di sekitar siswa. Kegiatan ini juga menuntut adanya kerjasama dan tanggungjawab di dalam diri siswa.

\section{Langkah kelima dalam $P Q 4 R$} adalah Recite, guru akan menginstruksikan kepada siswa untuk membuat outline atau intisari seluruh pelajaran yang telah dibahas hari ini. Guru nantinya dapat mengetahui indikator pemahaman setiap siswa dari hasil intisari yang dibuat oleh siswa tiap akhir pembelajaran. Pada pertemuan pertama fokus materi mengenai pengertian limbah, jenis-jenis limbah, dan dampak yang ditimbulkan limbah bagi lingkungan. Pada pertemuan kedua fokus materi pada cara penanganan limbah dan daur ulang limbah. Sejalan dengan pendapat Bahri (2008) bahwa merangkum tulisan merupakan aktivitas belajar siswa dengan tujuan agar catatan nantinya berguna dalam pencapaian tujuan belajar. Proses kegiatan meringkas meliputi membaca, memuncul kan gagasan, dan merangkum gagasan. Pada kegiatan meringkas terdapat proses mengevaluasi dan merevisi supaya tulisan menjadi bermakna.

Kegiatan terakhir adalah Review atau mengulang kembali, pada tahapan ini beberapa siswa akan mengutarakan hasil kegiatan pembelajaran hari ini secara lisan, siswa juga dapat mereview pertanyaan-pertanyaan yang telah dibuat, ide-ide pokok atau bagian materi yang sulit dari handout materi limbah yang diberikan guru. Puspito (2012) menyatakan bahwa dalam kegiatan review ini siswa dapat mengulang kembali hasil intisari tulisan yang telah dibuatnya dan meninjau ulang seluruh pertanyaan dan jawabannya secara singkat.

\section{Hasil Belajar Ranah Kognitif}

Nilai rata-rata tes kognitif siswa di kelas eksperimen yang menggunakan strategi $P Q 4 R$ dalam pembelajaran yaitu 88,240 . Nilai tersebut lebih tinggi dibandingkan dengan kelas kontrol yang menggunakan metode ceramah dan tanya jawab. Nilai rata-rata kognitif kelas 
kontrol sebesar 79,714. Hal ini karena strategi $P Q 4 R$ yang diterapkan di kelas eksperimen dengan materi pelajaran limbah dan daur ulangnya memberikan kesempatan siswa untuk mengembang kan kemampuan berpikirnya melalui kegiatan diskusi, membaca kritis materi limbah, dan perencanaan proses daur ulang limbah.

\section{Hasil Belajar Ranah Psikomotorik}

Hasil belajar ranah psikomotor berkenaan dengan keterampilan atau kemampuan bertindak setelah siswa menerima pengalaman belajar tertentu. Hasil belajar psikomotor ditunjukkan dengan keterampilan manual yang terlihat pada siswa dalam kegiatan fisik. Kegiatan yang dilakukan adalah mengidentifikasi jenis-jenis limbah. Penilaian hasil belajar ranah psikomotorik diperoleh melalui lembar observasi.

Nilai rata-rata psikomotor siswa kelas eksperimen yaitu 73,611 dan untuk kelas kontrol sebesar 57,857. Nilai ratarata psikomotorik siswa di kelas eksperimen yang menggunakan strategi $P Q 4 R$ dalam pembelajaran lebih tinggi dibandingkan dengan kelas kontrol yang menggunakan metode ceramah dan tanya jawab. Hal ini disebabkan karena strategi $P Q 4 R$ yang diterapkan di kelas eksperimen dengan materi pelajaran limbah dan daur ulangnya memberikan kesempatan siswa untuk aktif.

Kegiatan psikomotorik yang dilakukan pada strategi $P Q 4 R$ hanya muncul pada saat pertemuan pertama. Siswa melakukan observasi mengidentifikasi jenis limbah tersebut bersama-sama. Selain itu, juga dilaksanakan observasi di lingkungan tempat tinggal yang mengalami permasalahan karena limbah. Kegiatan ini bertujuan agar siswa melihat secara langsung dampak yang ditimbulkan limbah pada lingkungan jika pengolahan limbah dilakukan tidak tepat.

\section{Hasil Belajar Ranah Afektif}

Indikator afektif dalam pembelajaran IPA merupakan sikap yang diharapkan saat dan setelah siswa melakukan proses pembelajaran yang berkaitan dengan sikap ilmiah. Sikap ilmiah tersebut antara teliti, mandiri, tanggung jawab, aktif, jujur, dan menghargai pendapat teman.

Pada penelitian ini hasil belajar afektif diperoleh melalui lembar observasi. Penilaian melalui lembar observasi oleh observer diharapkan mampu mengukur afektif siswa secara eksternal.

Berdasarkan hasil uji hipotesis diketahui bahwa strategi $P Q 4 R$ berpengaruh positif untuk meningkatkan 
hasil belajar ranah afektif. Penelitian yang dilakukan di SMA N 1 Mojolaban dengan materi limbah dan daur ulangnya menunjukkan $100 \%$ siswa telah mencapai ketuntasan pada ranah afektif.

Berdasarkan pernyataan di atas terlihat bahwa seluruh kegiatan dalam pembelajaran $P Q 4 R$ meliputi preview, questions, read, reflect, recite, dan review mampu meningkatkan karakter dan keterampilan sosial siswa. Hal tersebut jelas menunjukkan bahwa strategi $P Q 4 R$ memberikan pengaruh positif terhadap hasil belajar biologi ranah afektif.

Hal-hal yang perlu diperhatikan dalam penerapan $P Q 4 R$ antara lain yaitu guru harus memahami dan mengetahui unsur-unsur dalam $P Q 4 R$. Guru harus bisa mencipatakan langkah pembelajaran preview, questions, read, reflect, recite, dan review dengan tepat sehingga perbedaan karakter siswa dalam belajar dapat terakomodasi dengan baik. Hal tersebut akan membawa pengaruh dalam meningkatkan hasil belajar siswa pada semua ranah.

\section{Kesimpulan}

Berdasarkan hasil penelitian dapat disimpulkan bahwa strategi $P Q 4 R$ berpengaruh nyata terhadap hasil belajar biologi siswa kelas X SMA Negeri 1
Mojolaban baik pada ranah kognitif, afektif maupun psikomotorik.

\section{Daftar Pustaka}

Bahri, S. (2008). Psikologi Belajar. Jakarta : Rineka Cipta

Jensen, E. (2011). Pemelajaran Berbasis Otak: Paradigma Pengajaran Baru (2nd eds). Terj. Benyamin Molan. Jakarta: PT. Indeks

Joyce, B., Weil, M., Calhoun, E. (2009). Models of Teaching: Model-model Pengajaran (8th eds). Terj. Achmad Fawaid \& Ateilla Mirza. Yogyakarta: Penerbit Pustaka Pelajar

Puspito, Y., Latifah., Sundari, S. (2012). Metode Pembelajaran Preview, Question, Read, Reflect, Recite, Review Strategi Concept Mapping. Journal Chemistry in Education, 2 (1), 149-153

Rachanah. (2009). Pengembangan Model Pembelajaran Berorientasi Konstuktivistik Untuk Meningkatkan Kualitas Pembelajaran Akuntansi Di SMA. Jurnal Penelitian Pendidikan, 10 (2): 1-14

Setiawan, I. G. (2008). Penerapan Pengajaran Berbasis Masalah Untuk Meningkatkan Hasil Belajar Biologi Siswa Kelas X.2 SMA Laboratorium Singaraja, Jurnal Penelitian dan Pengembangan Pendidikan, 2(1) : 4259

Siswandi, H.J. (2006). Meningkatkan Keterampilan Berkomunikasi Melalui Metode Diskusi Panel dalam Mata Pelajaran Bahasa Indonesia di Sekolah Dasar (Penelitian Tindakan Kelas), Jurnal Pendidikan Penabur 7: 24-35

Sudjana, N. (2010). Penilaian Hasil Proses Belajar Mengajar. Bandung : PT Remaja Rosdakarya

Suprijono, A. (2009). Cooperative Learning Teori dan Aplikasi Paikem. yogyakrta : pustaka pelajar.

Syah, M. (2005). Psikologi Pendidikan. Bandung : PT Remaja Rosdakarya 
Tanta. (2010). Pengaruh Gaya Belajar Terhadap Hasil Belajar Mahasiswa pada Mata Kuliah Biologi Umum Program Studi Pendidikan Biologi Universitas Cenderawasih, KREATIF Jurnal Kependidikan Dasar 1(1): 7-21

Tiemensma, L. (2009). Visual Literacy To Comics Or Not To Comics, World Library And Information Congress 75th IFLA General Conference And Council. Midrand Graduate Institute

Trianto. (2009). Mendesain Model Pembelajaran Inovatif-Progresif. Jakarta: Kencana.
Yusuf, Y \& Natalina, M. (2005). Upaya Peningkatan Hasil Belajar Biologi Melalui Pembelajaran Kooperatif Dengan Pendekatan Struktur di Kelas X 7 SLTP Negeri 20 Pekanbaru. Jurnal Biogenesis Vol. 2(1):8-12

Zaini, H. (2002). Strategi Pembelajaran Aktif. Yogyakarta : CTSD 